\title{
Root Growth Capacity in Coniferous Forest Trees
}

\author{
Roy F. Sutton \\ Forestry Canada, Ontario Region, Box 490, Sault Ste. Marie, Ont. P6A 5M7, Canada
}

Successful establishment of tree plantations depends on a chain of events that are even more complex in forestry than in horticulture, primarily because of differences in scale. Ideally, forest tree planting programs are conducted on a scale and with resources sufficient to allow the use of freshly lifted planting stock that is physiologically attuned to the planting environment; site preparation, stock handling and planting are done by skilled and adequately supervised labor; the species and ecotype of planting stock are ecologically suited to the sites planted; and prolonged drought never follows planting. The cause of any failure is generally clear.

In other cases, however, especially during times of rapid expansion of planting programs, the success or failure of a program is commonly judged by the number of trees planted and by adherence to a timetable, sometimes without regard to subsequent field performance. Maintaining the integrity of the regeneration chain becomes problematical. The higher costs of producing more stock, of storing or holding, and of distributing and planting, often lead to "economies" elsewhere. If insufficient resources are allocated to supervision and follow-up monitoring, failures may be commonplace, but unsuspected or unacknowledged.

Until recently, many foresters would be offended if they were accused of not knowing good planting stock when they saw it. Yet, even good-looking stock well-planted in a favorable environment may be doomed before it is planted. This was illustrated convincingly at Red Rock Nursery in British Columbia in 1977. Batches of lodgepole pine (Pinus contorta Dougl.) had been lifted the previous November, overwintered at $-2 \mathrm{C}$, removed from storage, and shipped on 3 May. From each batch, as it was shipped, a sample was planted in the nursery. When shipped, the batches were indistinguishable from one another in all external characteristics; yet, by the end of July, mortality was almost total in some batches and zero in others. Stock that had produced little or no new root growth after planting had died. One batch of planting stock, when planted by a given method in a given way on a given site, may flourish; another batch, identical in appearance, and treated identically, may perish. The concept of Root Growth Capacity (RGC) ( = Root Growth Potential $=$ Root Regenerating Potential) was fathered by such seemingly inexplicable mortality.

The objective of this paper is to review the concept of RGC and discuss the problems associated with its quantification and interpretation.

\section{ROOT GROWTH CAPACITY}

In the context of silviculture, RGC is defined as "the capacity of roots or root systems to extend existing roots and initiate new ones, especially after transplanting or outplanting" (Suttton and Tinus, 1983). The RGC of planting stock is estimated from the "new" root growth produced by a subsample in favorable growing conditions during a test period of specific length. The stock to be tested is potted in a growing medium or suspended in a hydroponic solution or an aeroponic mist chamber (Rietveld and Tinus, 1987). Test procedures have varied considerably (Table 1), but all, in some way, quantify the new white roots (or some class of them, e.g., those $\geq 1 \mathrm{~cm}$ long) and report this value as the RGC, usually as the mean of the RGCs for individual test plants. Some investigators (Stone and Schubert, 1959a, 1959b; Zaerr, 1967) remove any white roots present before a test to ensure their exclusion from RGC values determined subsequently. The RGC of planting stock that has been stored, with or without refrigeration, is determined in the same way as for newly lifted stock.

The term Rapid Root Regeneration Capacity (RRRC) has been applied loosely to that part of the RGC produced early in the test period. Leaf et al. (1978), for instance, used the term to emphasize the importance of minimizing the delay between planting and the onset of new root growth.

\section{DEVELOPMENT OF THE RGC CONCEPT}

Lead roles in developing the RGC concept were played by two individuals, Philip Wakeley, in the southeastern United States, and Edward Stone, in California.

\section{Philip Wakeley in the southeastern United States}

Wakeley (1971) joined the USDA Forest Service in 1924. The Southern pine planting program had begun only 5 years earlier, when the Great Southern Lumber Co. planted $\approx 8$ ha of wildings near Bogalusa, La. Within 50 years, the program would result in the establishment of 7,000,000 ha of longleaf (Pinus palustris Mill.), loblolly (P. taeda L.), slash ( $P$. elliottii Engelm.), and shortleaf ( $P$. echinata Mill.) pines in the southeastern United States.

Wakeley was directed to prepare a definitive technical bulletin on all phases of artificial restoration in the Southern pine region. 
This linkage between planting stock and field performance is necessary for evaluating planting stock quality.

Morphological grading of nursery stock initially worked well in the Southern pine program; i.e., the higher grades gave consistently superior performance than did the lower (Wakeley, 1935). However, reliability declined markedly after the great expansion of the program began in 1933-34 and new nurseries came into production (Wakeley, 1949). From studies involving > 122,000 trees from 1934 through 1941, Wakeley (1949) concluded that "some unidentified and uncontrolled influence frequently caused greater differences in initial survival than did drastic variations in planting technique." After further study of the water relations of newly set plants, Wakeley formulated the important hypotheses that: "(a) initial survival and height growth of planted southern pines depend on excess of water-intake over water-loss; and (b) excess of water-intake, in turn, often depends on formation of new root tissue promptly after planting."

\section{Edward Stone in California}

Wakeley's work prepared the way for Stone and his colleagues in California, who formally advanced the concept of RGC of forest tree planting stock in the 1950 s.

In California, only 30,000 ha were planted in almost 50 years in an organized forest tree planting program that dated from 1910; planting was held back for many reasons, "the most important being poor seedling survival and an inability to explain why" (Stone and Schubert, 1959b). Of the 12 million trees planted from 1950 through 1954 , at a cost of US\$830,000, "considerably fewer" than half survived (Stone, 1955). Some failures resulted from obvious causes, e.g., rodents, livestock, and competing vegetation, but others occurred without apparent reason (Stone, 1955).

That these inexplicable failures in California were related to the physiological condition of the planting stock had been suspected by some since the late 1930s (Schubert and Adams, 1971; Stone, 1955). However, it was Stone, who, in the mid-1950s, experimented specifically "for the purpose of determining whether or not physiological conditions resulting in low survival do occur" (Stone, 1955).

Stone, like Wakeley, believed that the most critical component of physiological condition of planting stock was the seedlings' capability of extending new root tissue into the soil soon after planting. The absence of root development, therefore, was the criterion used by Stone to indicate unsatisfactory physiological condition. In Stone's 1955 study, fall-lifted stock of five species was transplanted into 3.8-liter cans and moved into a greenhouse, in which favorable growth conditions were maintained. In all species, some trees failed to produce roots during the 60-day test. "Close examination of both seedlings that produced roots and those that failed to do so did not reveal any external morphological differences." The test trees were replanted for a further 120 days, by which time "almost all the seedlings which had not produced roots in the first 60 days were dead." The study was not designed to examine any manipulation of physiological condition, nor was genetic variation considered, and both the small number of trees used and the method of selecting stock from the nurseries precluded useful comparison of species, nurseries, or stock treatment. Nonetheless, this was the seminal study that opened the door to the whole question of root growth capacity in forest tree planting stock.

On the groundwork laid by Wakeley and Stone rests much of the subsequent research on the performance potential and quality of planting stock (Aboud et al., 1979; Day and Harvey, 1983; Day et al., 1985; Duryea, 1985; Gadgil and Harris, 1980; Hallgren and Tauer, 1987; Harvey and Day, 1983; Hermann and Lavender, 1979; Hinesley and Blazich, 1981; Kotisaari, 1982; Kotisaari and Räsänen, 1982; Larsen et al., 1986; Mattsson and Lindgren, 1981; Mattsson, 1982, 1986; Navratil et al., 1986; Parvianinen, 1982; Rietveld and Tinus, 1987; Ritchie and Dunlap, 1980; Ritchie, 1984, 1985; Sandvik, 1982a, 1982b; Schmidt-Vogt, 1980; Stupendick and Shepherd, 1979; Sutton, 1977, 1979).

\section{RGC VALUES-WHAT INFLUENCES THEM?}

The RGC value obtained from an RGC test, for any given prove- nance of any given species, reflects four main groups of influence: a) the character of the test plant at the start of the test; b) the test environment; c) the duration of the test; and d) the basis used to quantify RGC.

\section{a) The character of the test plant at the start of the test}

The morphological and physiological attributes of planting stock at the time of lifting are determined by the interaction of the genetic makeup of the stock with the nursery cultural regime and climate. Conventionally, the character of the test plant at the start of an RGC test is the same as that of the planting stock of interest; the test is run on a subsample of the parent planting stock. Hermann (1967), Lüpke (1972), and Hermann and Lavender (1979), however, have examined RGC both conventionally and in test plants that were subjected to further stress before being tested for RGC. The physiological mechanisms by which root system morphogenesis and growth are controlled probably include the export of photosynthate from shoot to root (see Ritchie, 1982; van den Driessche, 1978), but there is strong evidence for the involvement of growth regulators (Jackson and Stead, 1983; Zaerr and Lavender, 1974). At least four major groups of growth regulators may be considered active or potentially active: auxins, gibberellins, cytokinins, and abscisic acid (Torrey and Phillips, 1974). Growth regulators affect both the kind of roots produced (Coutts and Bowen, 1973; Weaver, 1972) and growth rates. Most experimental studies of the control of lateral root initiation have been based on root systems that are capable of initiating laterals both acropetally and otherwise. These studies have indicated that "lateral initiation is controlled by endogenous growth regulators and is susceptible to exogenous supplies" (Charlton, 1983). Zaerr (1967) applied indole-3-acetic acid (IAA) in lanolin at $0.01 \%$, $0.1 \%$, and $1.0 \%(\mathrm{w} / \mathrm{vl})$ or lanolin alone to ponderosa pine (Pinus ponderosa Laws.) transplants to determine the effect on RGC; he found that, although it may move from the top into the root, IAA had little influence on RGC. That a growth regulator may stimulate or inhibit, depending on its concentration (Lundegårdh, 1966), complicates the determination of interrelationships.

Prelifting influences on RGC. Progression through dormancy, especially in the pines, seems to be accompanied by physiological changes that strongly influence RGC (Lavender and Cleary, 1974). Any factor that influences the growth of nursery stock (e.g., cultural practice, soil moisture, and nursery climate) is likely to affect the RGC of that stock.

(i) Dormancy process and lifting date. The morphological and, especially, the physiological nature of planting stock can be influenced greatly by the time of lifting (Brissette and Roberts, 1984; Bunting, 1977; Dykstra, 1974a; Hallgren and Tower, 1987; Lavender and Wright, 1960; Mullin and Parker, 1976; Stone and Schubert, 1959b; Stone et al., 1962; Sutton, 1982a; Winjum, 1963). Many of the remarkable differences in field performance among trees planted after having been lifted at different times during the season, or after having been lifted at the same time from different nurseries, may be explained on the basis of the dormancy process and physiological condition (Stone, 1955; Stone and Schubert, 1959c). The use of planting stock in which dormancy has been prematurely interrupted is probably a major cause of the problems commonly experienced with early fall planting, especially of pines (Sutton, 1982a). A difference of 1 week in fall lifting date made a 20-fold difference in field survival rate of jack pine (Pinus banksiana Lamb.) (Mullin and Parker, 1976). The root growth and performance of field-planted Douglas fir (Pseudotsuga menziesii Mirb. France) also depend greatly on when the stock was lifted (Stone, 1955; Walters and Soos, 1961; Winjum, 1963).

(ii) Nursery cultural practice. In that cultural practices may vary among nurseries, planting stock from different nurseries in the same climatic region may differ in morphology and physiological response, including RGC (Stone et al., 1963; Stone and Jenkinson, 1971). Root wrenching and undercutting may increase (Bacon and Bachelard, 1978; Dykstra, 1974b), decrease (Abod and Sandi, 1983), or have no effect (Feret and Kreh, 1986; van den Driessche, 1978) on RGC. These contrary indications may derive from species differences, but more likely they reflect the wide variety of different treatments that receive the same label. 
Table 1. A partial list of studies involving root growth capacity (RGC) testing, indicating the factors studied and the range of differences in test environment, test duration, and quantification criteria.

\begin{tabular}{|c|c|c|c|c|c|}
\hline Species $^{2}$ & $\begin{array}{l}\text { Treatment or } \\
\text { factors studied }\end{array}$ & $\begin{array}{l}\text { Sample size, } \\
\text { replications, etc. }\end{array}$ & $\begin{array}{l}\text { Test } \\
\text { duration } \\
\text { (days) }\end{array}$ & $\begin{array}{c}\text { RGC quantification } \\
\text { criteria }\end{array}$ & Ref. \\
\hline $\begin{array}{l}\mathrm{pP}, \mathrm{mF}, \mathrm{jeP}, \\
\mathrm{cF}, \mathrm{dF}\end{array}$ & Species, variation & $\begin{array}{l}\text { Five samples of } 10 \text { seed- } \\
\text { lings in } 3.8 \text {-liter cans; } \\
\text { sandy loam }\end{array}$ & 60 & No. of new roots & Stone, 1955 \\
\hline $\mathrm{pP}$ & $\begin{array}{l}\text { Time of lifting, nursery, } \\
\text { seed source }\end{array}$ & $\begin{array}{l}\text { Two replicates of } 10 \\
\text { seedlings per crock in } \\
\text { each of four water baths } \\
(10,15,20 \text { and } 25 \mathrm{C})\end{array}$ & 30 & $\begin{array}{l}\text { New roots counted, those }>1 \mathrm{~cm} \\
\text { long measured }\end{array}$ & $\begin{array}{l}\text { Stone and Schubert, 1959a, } \\
1959 \mathrm{~b}\end{array}$ \\
\hline $\mathrm{pP}$ & $\begin{array}{l}\text { Auxin in relation to RGC } \\
\text { progression in } 3 \text { consec- } \\
\text { utive years, several seed } \\
\text { sources }\end{array}$ & $\begin{array}{l}\text { Ten seedlings per tray, } \\
\text { two replicates per lifting } \\
\text { date }\end{array}$ & 30 & $\begin{array}{l}\text { Total increase in length per } \\
\text { seedling, all roots that grew } 5 \\
\text { mm or more during test }\end{array}$ & Zaerr, 1967 \\
\hline $\mathrm{pP}$ & Lifting date & $\begin{array}{l}\text { Six replicates of four soil- } \\
\text { water treatments ( } 0.1 \text { to } \\
50 \text { bars suction) each }\end{array}$ & 28 & $\begin{array}{l}\text { Length of all roots that had } \\
\text { elongated at least } 1 \mathrm{~cm}\end{array}$ & Stone and Jenkinson, 1970 \\
\hline
\end{tabular}
50 bars suction), each replicate with 10 seedlings in each of four trays; sandy clay loam

pP

nS Plant water, saturation deficit, exposure, root dip, stock size

jP, wS Periodicity

wS

Soil moisture

jP, bS, wS Species, provenance, duration of storage

Species, periodicity

IP

Provenance, nursery, grade

$\mathrm{mP}$

Soil temperature, rate of development of new root growth, wrenching, \pm fertilization mersed in constant temperature water baths at 5 10,15 , and $20 \mathrm{C}$

$\mathrm{bC}$

RGC determination

Test tree roots suspended in mist chamber

Growth chamber, 60 trees/species/site 35,000 50,000 lux one tree/pot, peat : vermiculite
$2+2$ transplants treatment potted in sand,

Thirty-five trees/species, growth chambers, some environmental variation,

Eight single-tree root-box replications of three soil moisture tension treatbars); sandy loam

a) Hydroponic growth chamber, 40 trees/speduration; b) hydroponic tank, 32 trees/species/ provenance/storage duration

Five replicates of four trees, a) sandy loam, b) peat : vermiculite perature, $15-23 \mathrm{C}$ air
Length per seedling of all roots that had elongated at least $1 \mathrm{~cm}$ during test

35 Length of new roots

Stone and Jenkinson, 1971

Lüpke, 1972

72 Change in root area index

Hambly, 1973

40 Difference between initial and final root area index ${ }^{y}$

21 Short and long roots separately, number and length of new roots

Difference between initial and final root area index $\mathrm{x}^{\mathrm{y}}$, root elongation

28 a) Root volume displacement;

b) Root volume displacem

$0=$ no new roots,

1 = some new roots but none $>1 \mathrm{~cm}$,

$2=$ one to three new roots $>1$ $\mathrm{cm}$ long,

3 = four to 10 new roots $>1$ $\mathrm{cm}$ long,

$4=11$ to 30 new roots $>1 \mathrm{~cm}$ long, and

$5=>30$ new roots $>1 \mathrm{~cm}$ long

16, 32, Nonmycorrhizal roots only, new

55 apices $>2 \mathrm{~mm}$ counted, lengths of new members $>5 \mathrm{~mm}$ measured and their position on the root network (root order) recorded

10

Total root elongation, number of new roots, change in root area index ${ }^{y}$

30

RGC-a $=$ mean no. new roots $<1 \mathrm{~cm}$ long; $\mathrm{RGC}-\mathrm{b}=$ mean no. new roots $>1 \mathrm{~cm}$ long; RGC$c=$ mean aggregate length of roots >1 cm long; RGC-d = mean mean length of roots $>1$ $\mathrm{cm}$ long, all values per tree
Sutton, 1975, 1982a

Day and MacGillivray, 1975

Day et al., 1977

Burdett, 1979

Nambiar, 1979

Day, 1982; Day et al., 1985

Sutton, 1983, 1987

PP Pinus ponderosa Laws, jeP = Pinus jeffreyi Grev, et Balf., $\mathrm{mF}=$ Abies magnifica A. Murr., cF = Abies concolor Lindl., dF = Pseudotsuga menziesii [Mirb.] Franco, $\mathrm{mP}=$ Pinus radiata D. Don, IP = Pinus contorta Dougl., jP = Pinus banksiana Lamb., bS = Picea mariana (Mill.) B.S.P. $\mathrm{nS}=$ Picea abies. Karst., wS = Picea glauca (Moench) Voss, bC = boreal conifers.

y Root area index, square centimeter of root surface area, determined using the method of Morrison and Armson (1968). 
Nutrition in the nursery is also important. Benzian and her coworkers (Benzian and Freeman, 1967, 1970; Benzian et al., 1974) in the United Kingdom demonstrated an effect that has often gone unrecognized. Rather heavy top-dressings of nitrogenous fertilizer were applied to nursery stock late in the growing season, without affecting the morphology of the stock, and thereby boosted the nitrogen concentration and content of the stock. The unboosted stock was good, high-class stock, and, although late-season application of nitrogen is often deplored on the grounds that it makes for succulence and increased susceptibility to frost and winterkill, the results showed that the performance of boosted Sitka spruce [Picea sitchensis (Bong.) Carr.] planted on harsh sites was significantly improved. It is tempting to speculate that RGC was enhanced in the boosted stock. In any event, there is also "considerable evidence that differences in soil fertility may cause large differences in assimilate allocation to roots" (Landsberg and McMurtrie, 1985). Keyes and Grier (1981), for instance, found that annual net primary production was $7.3 \mathrm{t} \cdot \mathrm{ha}^{-1}$ above ground and $8.1 \mathrm{t} \cdot \mathrm{ha}^{-1}$ below ground in 40-year-old Douglas fir on relatively infertile sites in Oregon, whereas annual net primary production was $13.7 \mathrm{t} \cdot \mathrm{ha}^{-1}$ above ground and only $4.1 \mathrm{t}^{-1} \mathrm{ha}^{-1}$ below ground on relatively fertile sites. Allocation to the roots on the poor site represented $53 \%$ of dry matter production, compared with $23 \%$ on the more productive site. Below-ground allocation of carbon decreased in young Scots pine (Pinus sylvestris L.) after irrigation and fertilization (Linder and Axelsson, 1982), as calculated from the data of Persson (1980).

Soil moisture stress in the nursery at the time of lifting depressed RGC of white spruce [Picea glauca (Moench) Voss] and black spruce [P. mariana (Mill.) B.S.P.] planting stock (Stone and Schubert, 1959b). Day et al. (1977) noted that: "[i]n a dry spring season, in the absence of irrigation, the [RGC] can be expected to decline to dangerously low levels even during the normal spring lifting period." However, Abod and Sandi (1983) found that restricted watering of Caribbean pine (Pinus caribaea Mor. var. hondurensis B and G) in a nursery in peninsular Malaysia significantly $(P<0.05)$ increased the RGC in comparison with seven other treatments, including watering frequencies of 1,3 , and 6 days.

(iii) Nursey climate. The pronounced influence of nursery climate on the seasonal periodicity in RGC seems, in some species at least, to depend largely on the number of consecutive cool nights (Krugman and Stone, 1966; Stone and Norberg, 1971); in one nursery, the peak development of RGC of ponderosa pine planting stock shifted by more than 2 months in 3 years (Stone and Jenkinson, 1959c). Stone and Schubert (1954a, 1959b) found that nursery soil temperature influenced the number of new lateral roots initiated, the number of initially present roots that resumed growth, and the amount of lateral root elongation after the ponderosa pine seedlings had been transplanted in the greenhouse. Similarly, planting stock grown in nurseries with different climates may be expected to exhibit differences in RGC. Not all species of conifer, nor all provenances of a given species (Nambiar et al., 1982; Stone and Schubert, 1959 c), are affected equally by the nursery climate; but, in the several species studied by Stone and Norberg (1971), when budbreak was largely controlled through cumulative exposure to low air temperatures, then so was RGC.

\section{Postlifting, pre-test influences on RGC}

(i) Storage. The effect of storage depends on the interaction between the characteristics of the stock when lifted, the storage environment, and the duration of storage. At least with ponderosa pine, refrigerated storage reduces RGC of stock lifted in early fall, increases RGC of stock lifted in early winter when RGC is increasing, and reduces RGC of stock lifted at or after the RGC peak (Stone and Jenkinson, 1971). Refrigeration can be used to prolong the availability of planting stock with acceptable RGC.

(ii) Handling procedures and mechanical perturbation. Handling can have a major influence on the RGC of planting stock (cf. Sutton, 1980a, 1982b; Tabbush, 1986a, 1986b). Almost all plants and plant parts respond in some way to mechanical perturbation (Biro and Jaffe, 1984; Jaffe, 1976, 1980; Jaffe and Telewski, 1984; Jaffe, 1985, 1987; Stupendick and Shepherd, 1979; Takahashi and Jaffe, 1984). As Tabbush (1986b) pointed out, all operations from lifting through planting involve physical shock. The effect of successive shocks is likely to be cumulative. I have seen a convincing instance of marked reduction of growth in nursery stock merely as a consequence of periodic remeasurement.

Tabbush (1986a, 1986b), in the United Kingdom, studied the effect of rough handling on $1+1$ Sitka spruce 15 to $20 \mathrm{~cm}$ tall. The trees were lifted in the fall and cool-stored at 0 to $2 \mathrm{C}$ until spring, when they were removed from storage and culled to reduce the variability of stock used for the study. Forty trees (not bundled) were sealed into each of four polyethylene bags. One bag served as a control, and the others were dropped from a height of $3 \mathrm{~m}$ onto a hard floor one, five, or 15 times. Except for the dropping treatment, plants were handled with great care throughout. After treatment, 10 trees were tested for RGC by Burdett's (1979) method of rating. The remaining 30 plants per treatment were planted in the nursery, and their performance was assessed at the end of the growing season. The dropping treatment, which did not visibly damage any roots, depressed not only RGC but also the rate of root growth. A single impact seems to have been enough to depress the growth rate, and the negative correlation between number of impacts and growth rate is clear. First-year survival was significantly depressed by the most severe treatment. Another study by Tabbush (1986b) in the same series showed that the amount of mycorrhizal development decreased with severity of handling in both Sitka spruce and Douglas fir. Reduction in mycorrhizal development would be expected to contribute to water stress; Reid and Bowen (1979) have shown the importance of far-ranging "exploratory" hyphae in water uptake.

The large effect that can result from differences in stock handling procedures was readily apparent in a plantation of radiata pine $(\mathrm{Pi}$ nus radiata D. Don) in New Zealand (Sutton, 1979). Although all trees had been planted in the same operation, some had passed through the conventional procedure of lifting, culling, sorting, grading, root trimming, tying, packing, and hand-planting from planting bags. Other trees had been lifted, placed in rigid, plastic-lined cardboard planting boxes, and kept there until planted-out. Ironically, the purpose of the study had nothing to do with concern about the effects of handling. All that had been intended was a test of the acceptability to planting crews of the planting box in comparison with the conventional planting bag. Follow-up inspection had not been scheduled, but the detrimental effect of handling on performance proclaimed itself by obviously reduced survival rates and, among survivors, slower growth of the conventionally handled trees.

\section{b) The test environment}

At the time of sampling for RGC testing, coniferous planting stock may have a certain capacity for root growth. The expression of this capacity, however, is much influenced by the environment in which the test is carried out (Rietveld and Tinus, 1987; Stone and Jenkinson, 1970). Even minor differences in the test environment can produce substantial differences in RGC values (Sutton, 1975). Although test environments that favor root growth are usual in RGC testing practice, their superiority over more stressful environments is not self-evident when correlations between RGC and field performance are being examined. The amount of available soil water in the RGC test environment has been shown to influence the RGC of ponderosa pine (Stone, 1967; Stone and Jenkinson, 1970), jack pine, and white spruce (Hambly, 1973). Stone and Jenkinson (1970) found that the influence of available water on root growth varied with lifting date; with initial soil moisture tension of 0.5 $\mathrm{MPa}$, some root elongation took place in all tests; but only $\mathrm{i}$. the January test was there appreciable root elongation with soil moisture suction of 0.9 MPa. Light intensity (Abod et al., 1979), photoperiod (Thompson and Timmis, 1978), and air and soil temperatures (Abod et al., 1979; Nambiar et al., 1982; Stupendick and Shepherd, 1979; Thompson and Timmis, 1978) significantly influenced RGC in three pine species and Douglas fir.

\section{c) The duration of the test}

The RGC values obtained from a test obviously depend on the length of the test. Tests have ranged from 7 to 72 days (see Table 
1). Data reported by Nambiar et al. (1979) for unwrenched radiata pine seedlings show very large increases in the number of new root apices $>2 \mathrm{~mm}$ and length of new roots $>5 \mathrm{~mm}$ between days 32 and 55 in tests at several soil temperatures. Burr et al. (1987) found that 7-day RGC tests of ponderosa pine, Douglas fir, and Engelmann spruce [Picea engelmannii (Parry) Engelm.] that had not been cold-acclimated were less useful in predicting performance than were 14-day tests, but, especially in ponderosa pine, 7-day tests were better than 14-day tests as an indicator of the onset of deacclimation.

\section{d) Quantification of RGC}

The problem of quantification has two main facets. The first is the great amount of genetic variation associated with the rooting characteristics of higher plants (Caldwell, 1979; Hallgren and Tauer, 1987; Landsberg and McMurtrie, 1985). As noted by Caldwell (1979), casual observation might suggest that structural diversity of the root systems among plant species is rather limited. Apart from elaborated storage organs, the root systems of all plants consist of a dendritic structure with several orders of branching, commonly many more than in the shoot system. However, "a closer inspection certainly reveals variation among species in characteristics such as degree of branching, growth patterns, rooting density, and distribution of root hairs and secondary thickening, as well as physiological characteristics (Troughton and Whittington, 1969; Zobel, 1975)" (Caldwell, 1979). Intraspecific variation may also be large (Dykstra and Gatherum, 1967; Dykstra, 1974c; Martinsson and Lundh, 1982; Nambiar et al., 1982).

The second facet is that the objective of an RGC test is to quantify the capacity of the planting stock for producing new root growth after planting, with a view to assessing the potential of the planting stock for field survival and growth. This facet of quantification, therefore, can be reduced to the choice of a measure of RGC closely related to performance potential. The many possible bases include: aggregate length of "new" roots (i.e., all roots, or extensions of roots, produced during the test period); aggregate length of all new roots longer than an arbitrary minimum; total number of new roots; number of new roots longer than an arbitrary minimum; numbers of new roots of various arbitrary length classes; mass or volume of new roots; and the increase or rate of increase of root surface area during the test. A major difficulty is that interrelationships among the various components or expressions of RGC (e.g., number and length of new roots) are not constant (Sutton, 1987). A further complication is the long and short root habit in heterorhizic species (Sutton, 1969, 1980b), typical of coniferous species used in forestation. The choice of base will have a major effect on the RGC value reported.

\section{PROBLEMS IN RELATING RGC TO FIELD PERFORMANCE}

Relationships between RGC and field performance are elusive and difficult to investigate. On one hand, "the importance of root growth in the establishment of outplants can be presumed..." (Burdett et al., 1983), and the thesis that "the greater the RGC...the greater will be the ability of such stock to survive and grow well" (Sutton, 1980a) would seem to be reasonable. However, although correlations between RGC and survival have been reported (Hallgren and Tauer, 1987; Larsen et al., 1986), the hypothesis is not well-supported by data (Sutton, 1987). Indeed, the essentiality of new root growth to the survival and early growth of a newly planted tree has been questioned: "[t]he necessity of new root growth hinges on several questions: Is absorption of water and nutrients confined to new, unsuberized roots? Are viable root hairs critical in the absorption process? If effective absorption is indeed dependent on new root tissues, is it the suberization of roots, which normally takes place within a few weeks of root formation, that effectively curtails the functional activity of roots? What is the adaptive significance of suberization? Is new root growth necessary simply to relocate centers of nutrient and water absorption in the soil profile so as to avoid localized depletion of water or nutrients?" (Caldwell, 1979). The answers to these questions might well depend on how well a plant is established; even when well-planted, a bare-root plant will not at first have its roots in effective contact with the soil throughout their length, and some roots will be bent and twisted (Sutton, 1978), and, after it is planted, even a containerized plant must extend its root system into the surrounding soil before effective root-soil contact can be established.

Certainly the outlook is bleak for a plant that has little or no RGC. Conversely, planting stock that has a very high RGC can be expected to perform well, at least within the limits imposed by the conditions it experiences at the planting site. For instance, McMinn (1980) found that RGC of white spruce was a good predictor of field performance only when RGC was relatively high or relatively low. Moreover, Sutton's (1980c) first- through fourth-year data from field plantings of jack pine, black spruce, and white spruce showed only scattered and unpatterned correlations between RGC and field performance. In another study, Sutton (1983) found that large differences in RGC did not influence performance of jack pine planted in a low-stress environment in a nursery; significant differences in black spruce performance were associated with order-of-magnitude differences in RGC. Root growth capacity and performance were not linearly related in either species. In field plantings, of the four criteria examined, only RGC-d (the average mean length of roots $>1 \mathrm{~cm}$ produced during the test) was consistently correlated with performance; RGC-d was correlated significantly $(P<0.01)$ with third- and fifth-year survival rates in both jack pine and black spruce. Growth and RGC were not correlated.

Horticulture may be better able than forestry to capitalize on any relationship that can be established between RGC and performance, as the possibility of controlling the outplanting environment is generally greater in horticulture than in forestry. However, Burdett's (1979) comment remains true: "it is by no means clear under what circumstances or to what degree root growth capacity affects the survival of field-planted trees."

\section{CONCLUDING COMMENTS}

The post-planting development of roots or root systems of coniferous planting stock is determined by many factors, some physiological, some environmental. Unsatisfactory rates of post-planting survival unrelated to the morphology of the stock, led, more than 30 years ago, to attempts to test the physiological condition of planting stock, particularly to quantify the propensity to produce new root growth. New root growth can be assumed to be necessary for successful establishment of stock after planting, but although the thesis that RGC is positively related to field performance would seem to be reasonable, supporting evidence has been meager.

Several major problems militate against greater use of RGC in forestry. These include: unstandardized techniques; unstandardized quantification; uncertain correlation between quantified RGC and field performance; variability within given, nominally identical, kinds of planting stock; and the irrelevance of RGC test values determined on a sub-sample of a parent population that subsequently, before it is planted, undergoes any substantive physiological or physical change. In its present form, RGC testing is silviculturally useful chiefly as a means of detecting planting stock that, while visually unimpaired, is moribund. To date, performance potential can be predicted from RGC with confidence only when RGC is either very high or very low. With the possibility of giving more attention to individual plants, and providing greater control of the cultural regime and environment, the horticultural application of RGC may be greater than the silvicultural.

\section{Literature Cited}

Abod, S.A., K.R. Shepherd, and E.P. Bachelard. 1979. Effects of light intensity, air and soil temperatures on root regenerating potential of Pinus caribaea var. hondurensis and P. kesiya seedlings. Austral. For. Res. 9:173-184.

Abod, S.A. and S. Sandi. 1983. Effect of restricted watering and its combination with root pruning on root growth capacity, water status and food reserves of Pinus caribaea var. hondurensis seedlings. Plant \& Soil 71:123129.

Bacon, G.J. and E.P. Bachelard. 1978. The influence of nursery conditioning treatments on some physiological responses of recently transplanted 
seedlings of Pinus caribaea Mor. var. hondurensis B. and G. Austral. For. Res. 8:171-183.

Benzian, B. and S.C.R. Freeman. 1967. Effect of "late-season" N and K top-dressings applied to conifer seedlings and transplants, on nutrient concentrations in the whole plant and on growth after transplanting. Rpt. For. Res., For. Commission, London. p. 135-140.

Benzian, B. and S.C.R. Freeman. 1970. Nursery and forest extension experiments in tree nutrition. Rpt. For. Res., For. Commission, London.

Benzian, B., R.M. Brown, and S.C.R. Freeman. 1974. Effect of late-season top-dressings of $\mathrm{N}$ (and $\mathrm{K}$ ) applied to conifer transplants in the nursery on their survival and growth on British forest sites. Forestry 47:153-184.

Biro, R. and M.J. Jaffe. 1984. Thigmomorphogenesis: ethylene evolution and its role in the changes observed in mechanically perturbed bean plants. Physiol. Plant. 62:289-296.

Brissette, J.C. and T.C. Roberts. 1984. Seedling size and lifting date effects on root growth potential of loblolly pine from two Arkansas nurseries. USDA For. Serv., Tree Planters' Notes 35:34-38

Bunting, W.R. 1977. Discussion, p. 86. In: R.F. Sutton (ed.). Plantation establishment symposium. Dept. Environ., Can. For. Serv., Sault Ste. Marie, Ont., Symp. Proc. O-P-5.

Burdett, A.N. 1979. New methods for measuring root growth capacity: their value in assessing lodgepole pine stock quality. Can. J. For. Res. 9:6367.

Burdett, A.N., W.R. Simpson, and C.F. Thompson. 1983. Root development and plantation establishment success. Plant \& Soil 71:103-110.

Burr, K.E., R.W. Tinus, S.J. Wallner, and R.M. King. 1987. Comparison of time and method of mist chamber measurement of root growth potential, p. 77-86. In: T.D. Landis (tech. coord.). Meeting the challenge of the nineties. Proc. Intermountain Forest Nursery Assn., Aug. 1987, Oklahoma City. USDA For. Serv., Gen. Tech. Rpt. RM-151.

Caldwell, M.M. 1979. Root structure: the considerable cost of below-ground function, p. 408-427. In: O.T. Solbrig, S. Jain, G.B. Johnson, and P.H. Raven (eds.). Topics in plant population biology. Cambridge Univ. Press, New York.

Charlton, W.A. 1983. Patterns and control of lateral root initiation, p. 113. In: M.B. Jackson and A.D. Stead (eds.). Growth regulators in root development. Brit. Plant Growth Regulat. Group, Monogr. 10.

Coutts, M.P. and M.R. Bowen. 1973. Tree physiology, Rept. For. Res., For. Commission, London. p. 89-93.

Day, R.J. and G.R. MacGillivray. 1975. Root regeneration of fall-lifted white spruce nursery stock in relation to soil moisture content. For. Chron. 51:196-199.

Day, R.J., J.T. Stupendick, and J.M. Butler. 1977. Root periodicity and root regeneration potential are keys to successful plantation establishment, p. 19-21. In: R.F. Sutton (ed.). Plantation establishment symp. Dept. Environ., Can. For. Serv., Sault Ste. Marie, Ont., Symp. Proc. O-P-5.

Day, R.J. 1982. Evaluating root regenerating potential of bareroot nursery stock, p. 83-96. In: R. Huber (comp.). Proc. 1981 Intermountain Nurseryman's Assn. Mtg., Dept. Environ., Can. For. Serv., Edmonton, Alberta, Info. Rpt. NOR-X-241.

Day, R.J. and E.M. Harvey. 1983. The morphological and physiological stock quality in relation to field outplanting performance (Prog. Rpt. 1982-1983). School of For., Lakehead Univ., Thunder Bay, Ont.

Day, R.J., W.R. Bunting, C. Glerum, E.M. Harvey, B. Polhill, K.H. Reese, and A. Wynia. 1985. Evaluating the quality of bareroot forest nursery stock. Ont. Min. Nat. Resour., Toronto.

Duryea, M.L. (ed.). 1985. Evaluating seedling quality: Principles, procedures, and predictive abilities of major tests. For. Res. Lab., Oregon State Univ.; Corvallis.

Dykstra, G.F. and G.E. Gatherum. 1967. Physiological variation of Scotch pine seedlings in relation to provenance and nitrogen. Iowa State J. Sci. 41:487-502.

Dykstra, G.F. 1974a. Effect of lifting date on electrical impedance, survival, and root-regeneration of lodgepole pine (Pinus contorta Dougl.) seedlings. B.C. For. Serv., Res. Note 60.

Dykstra, G.F. 1974b. Undercutting depth may affect root-regeneration of lodgepole pine seedlings. USDA For. Serv., Tree Planters' Notes 25:2122.

Dykstra, G.F. 1974c. Drought resistance of lodgepole pine seedlings in relation to provenance and tree water potential. B.C. For. Serv., Res. Note 62 .

Feret, P.P. and R.E. Kreh. 1986. Effect of undercutting on loblolly pine seedling size and its relation to root growth potential. Southern J. Applied For. 10:24-27.

Gadgil, P.D. and J.M. Harris. (eds.). 1980. Planting stock quality. Special issue of papers presented at the IUFRO workshop on "Techniques for Evaluating Planting Stock Quality", New Zealand. J. For. Sci. 10.

Hallgren, S.W. and C.G. Tauer. 1987. Effects of lift date, storage, and family on early survival and root growth potential of shortleaf pine, $p$. 87-92. In: T.D. Landis (tech. coord.). Meeting the challenge of the nineties; Proc. Intermountain Forest Nursery Assn., Aug. 1987, Oklahoma City. USDA For. Serv.. Gen. Tech. Rpt. RM-151.

Hambly, E.S.L. 1973. Periodicity in the root growth capacity of jack pine, black spruce, and white spruce nursery seedlings. MS Thesis. Fac. For., Univ, of Toronto.

Harvey, E.M. and R.J. Day. 1983. Evaluating the root regeneration potential of coniferous nursery stock by the potting and root mist chamber methods. School of For., Lakehead Univ., Thunder Bay, Ont.

Hermann, R.K. 1967. Seasonal variation in sensitivity of Douglas-fir seedlings to exposure of roots. For. Sci. 13:140-149.

Hermann, R.K. and D.P. Lavender. 1979. Testing the vigor of coniferous planting stock. Oregon State Univ., Corvallis, For. Res. Note 63.

Hinesley, L.E. and F.A. Blazich. 1981. Influence of postseverance treatments on the rooting capacity of Fraser fir stem cuttings. Can. J. For. Res. 11:316-323.

Jackson, M.B. and A.D. Stead (eds.). 1983. Growth regulators in root development. Brit. Plant Growth Regulat. Group, Wantage, Oxford, England, Monogr. 10

Jaffe, M.J. 1976. Thigmomorphogenesis: electrical resistance and mechanical correlates of the early events of growth retardation due to mechanical stimulation in beans. Z. Pflanzenphysiol. 78:24-32.

Jaffe, M.J. 1980. Morphogenetic responses of plants to mechanical stimuli or stress. Bioscience 30:239-243.

Jaffe, M.J. and F.W. Telewski. 1984. Thignomorphogenesis: callose and ethylene in the hardening of mechanically stressed plants, p. 79-95. In: B.N. Timmerman, C. Steelink, and F.A. Loewus (eds.). Phytochemical adaptations to stress. Plenum, New York.

Jaffe, M.J. 1985. Wind and other mechanical effects in the development and behavior of plants, with special emphasis on the role of hormones. Encyclopedia of plant physiology, New Series. vol. 11. Springer-Verlag, Berlin.

Jaffe, M.J. 1987. Models of thigmomorphogenesis in plants, p. 139-143. In: D.W. Newman and K.G. Wilson (eds.). Models in plant physiology and biochemistry. vol. II. CRC Press, Boca Raton, Fla.

Keyes, M.R. and C.C. Grier. 1981. Above- and below-ground net production in 40-year-old Douglas-fir stands on low and high productivity sites. Can. J. For. Res. 11:599-605.

Kotisaari, A. 1982. Preliminära resultat om rotregeneration och växtrytm hos barrotsplantor av tall, p. 83-89. In: H. Hultén (ed.). Rotdeformationer hos skogsplantor: Nordiskt Symposium. Swedish Univ. Agr. Sci. Dept. For. Yield Res., Rpt. 8.

Kotisaari, A. and P.K. Räsänen. 1982. Root growth potential and growth rhythm in planted Pinus sylvestris seedlings, p. 49-52. In: H. Hultén (ed.). Root deformation of forest tree seedlings: Proc. Nordic Symp. Dept. For. Yield Res., Swedish Univ. Agr. Sci., Garpenberg. Rpt. 11.

Krugman, S.L. and E.C. Stone. 1966. The effect of cold nights on the rootregenerating potential of ponderosa pine seedlings. For. Sci. 12:451-459.

Landsberg, J.J. and R. McMurtrie. 1985. Models based on physiology as tools for research and forest management, p. 214-228. In: J.J. Landsberg and W. Parsons (eds.). Research for forest management. CSIRO, Div. For. Res., East Melbourne, Australia.

Larsen, H.S., D.B. South, and J.M. Boyer. 1986. Root growth potential, seedling morphology and bud dormancy correlate with survival of loblolly pine seedlings planted in December in Alabama. Tree Physiol. 1:253 263.

Lavender, D.P. and B. Cleary. 1974. Coniferous seedling production techniques to improve seedling establishment, p. 177-180: In: R.W. Tinus, W.I. Stein. and W.E. Balmer (eds.). Proc. North American Containerized Forest Tree Seedling Symp., Great Plains Agr. Counc. Publ. 68.

Lavender, D.P. and E. Wright. 1960. Don't lift Douglas-fir seedlings too early because late lifting increases survival and vigor, studies show. Timberman 61(8):54-55.

Leaf, A.L., P. Rathakette, and F.M. Solan. 1978. Nursery seedling quality in relation to plantation performance, p. 45-51. In: E.E. Van Eerden and J.M. Kinghorn (eds.). Root Form of Planted Trees Symp. B.C. Min. For./Can. For. Serv., Victoria, Joint Rpt. 8.

Linder, S. and B. Axelsson. 1982. Changes in carbon uptake and allocation patterns as a result of irrigation and fertilization in a young Pinus sylvestris stand, p. 38-44. In: R.H. Waring (ed.). Carbon uptake and allocation in subalpine ecosystems as a key to management. For. Res. Lab., Oregon State Univ., Corvallis.

Lundegårddh, H. 1966. Plant physiology. Oliver and Boyd, Edinburgh, U.K.

Lüpke, B. v. 1972. Wurzelregeneration und Trockensubstanzproduktion nach dem Verpflanzen bei jungen Fichten unterschiedlichen Frischezustandes. Allg. Forst-u. J.-Ztg. 143:172-176.

Martinsson, O. and J.-E. Lundh. 1982. Contortatallens rotstabilitet-proveniensens inflytande, p. 145-163. In: H. Hultén (ed.). Rotdeformationer hos Skogsplantor: Nordiskt Symp. Dept. of For., Swedish Univ. Agr. Sci., Garpenberg. Yield Res., Rpt. 8. 
Mattsson, A. and A. Lindgren. 1981. Planteringstidpunktens inverkan på plantutvecklingen: en jämförelse mellan fryslagrat och på friland övervintrat täckrotsmaterial av tall och gran. Dept. For. Yield Res., Swedish Univ. Agr. Sci., Stencil 8.

Mattsson, A. 1982. Root growth capacity: An expression for plant quality, p. 24-27. In: P. Puttonen (ed.). Vitality and quality of nursery stock, Nordic Symp. Univ. Helsinki, Dept. Silvicult., Res. Note 36.

Mattsson, A. 1986. Seasonal variation in root growth capacity during cultivation of container grown Pinus sylvestris seedlings. Scand. J. For. Res. $1: 473-484$

McMinn, R.G. 1980. Root growth capacity and field performance of various types and sizes of white spruce stock following outplanting in the central interior of British Columbia, p. 37-41. In: H. Schmidt-Vogt (ed.). Characterization of plant material. Proc. IUFRO Working Group S1.05-04 Mtg. Freiburg im Breisgau. Waldbau-Institut Univ., Freiburg, F.R.G.

Morrison, I.K. and K.A. Armson. 1968. The rhizometer: a new device for measuring roots of tree seedlings. For. Chron. 44:21-23.

Mullin, R.E. and J.D. Parker. 1976. Provisional guidelines for fall lifting for frozen overwinter storage of nursery stock. For. Chron. 52:22-25.

Nambiar, E.K.S., G.D. Bowen, and R. Sands. 1979. Root regeneration and plant water status of Pinus radiata D. Don seedlings transplanted to different soil temperatures. J. Expt. Bot. 30:1119-1131.

Nambiar, E.K.S., P.P. Cotterill, and G.D. Bowen. 1982. Genetic differences in the root regeneration of radiata pine. J. Expt. Bot. 33:170-177.

Navratil, S., L.G. Brace., and I.K. Edwards. 1986. Planting stock quality monitoring. Dept. Environ., Can. For. Serv., Edmonton, Alberta, Info. Rpt. NOR-X-279.

Parvianinen, J. 1982. Root regeneration capacity and root/shoot ratio as indicator of future height differences between different types of barerooted nursery stock, p. 28-44. In: P. Puttonen (ed.). Vitality and quality of nursery stock. Nordic Symp. Dept. of Silvicult., Univ. of Helsinki. Res. Note 36.

Persson, H. 1980. Fine-root dynamics in a Scots pine stand with and without near-optimum nutrient and water regimes. Acta Phytogeog. Suec. 68:101110.

Reid, C.P.P. and G.D. Bowen. 1979. Effect of water stress on phosphorus uptake by mycorrhizas in Pinus radiata. New Phytol. 83:103-107.

Rietveld, W.J. and R.W. Tinus. 1987. Alternative methods to evaluate roo growth potential and measure root growth, p. 70-76. In: T.D. Landis (tech. coord.). Meeting the challenge of the nineties: Proc. Intermountain Forest Nursery Assn., Aug. 1987, Oklahoma City. USDA For. Serv., Gen. Tech. Rpt. RM-151.

Ritchie, G.A. and J.R. Dunlap. 1980. Root growth potential: its development and expression in forest tree seedlings. New Zealand J. For. Sci. 10:218-248.

Ritchie, G.A. 1982. Carbohydrate reserves and root growth potential in Douglas-fir seedlings before and after cold storage. Can. J. For. Res. 12:905-912.

Ritchie, G.A. 1984. Assessing seedling quality, p. 243-259. In: M.L. Duryea and T.D. Landis (eds.). Forest nursery manual: Production of bareroot seedlings. Nijhoff/Junk, The Hague, The Netherlands.

Ritchie, G.A. 1985. Root growth potential: principles, procedures and predictive ability, p. 93-105. In: M.L. Duryea (ed.). Evaluating seedling quality: Principles, procedures, and predictive abilities of major tests. For. Res. Lab. Oregon State Univ., Corvallis.

Sandvik, M. 1982a. Rotvekstkapasitet og rotvekstbetingelser, p. 69-81. In: H. Hultén (ed.). Rotdeformationer hos skogsplantor: Nordiskt Symp. Dept. For. Yield Res., Swedish Univ. Agr. Sci. Rpt. 8.

Sandvik, M. 1982b. Root growth capacity and root growth conditions, p. 42-48. In: H. Hultén (ed.). Root deformation of forest tree seedlings: Proc. Nordic Symp. Dept. For. Yield Res., Swedish Univ. Agr. Sci., Garpenberg. Rpt. 11.

Schmidt-Vogt, H. (ed.). 1980. Characterization of plant material. Proc. IUFRO Working Group S1.05-04 Mtg. Freiburg im Breisgau. WaldbauInstitut Univ., Freiburg, F.R.G.

Schubert, G.H. and R.S. Adams. 1971. Reforestation practices for conifers in California. Calif. Resource Agency, Dept. Conserv., Div. For., Sacramento.

Stone, E.C. 1955. Poor survival and the physiological condition of planting stock. For. Sci. 1:90-94.

Stone, E.C. and G.H. Schubert. 1959a. Seasonal periodicity in root regeneration on ponderosa pine transplants: A physiological condition. Proc. Soc. Amer. For. 1958:154-155.

Stone, E.C. and G.H. Schubert. 1959b. Root regeneration by ponderosa pine seedlings lifted at different times of the year. For. Sci. 5:322-332.

Stone, E.C. and G.H. Schubert. 1959c. The physiological condition of ponderosa pine (Pinus ponderosa Laws.) planting stock as it affects survival after cold storage. J. For. 57:837-841.

Stone, E.C., J.L. Jenkinson, and S.L. Krugman. 1962. Root-regenerating potential of Douglas-fir seedlings lifted at different times of the year. For. Sci. 8:288-297.

Stone, E.C., G.H. Schubert, R.W. Benseler, F.J. Baron, and S.L. Krugman. 1963. Variation in the root regenerating potentials of ponderosa pine from four California nurseries. For. Sci. 9:217-225.

Stone, E.C. 1967. The root-regenerating capacity of seedling transplants and the availability of soil moisture. Ann. Arid Zone 6:45-57.

Stone, E.C. and J.L. Jenkinson. 1970. Influence of soil water on root growth capacity of ponderosa pine transplants. For. Sci. 16:230-239.

Stone, E.C. and J.L. Jenkinson. 1971. Physiological grading of ponderosa pine nursery stock. J. For. 69:31-33.

Stone, E.C. and E.A. Norberg. 1971. Modification of the nursery climate to improve root growth capacity of ponderosa pine transplants. Amer. Soc. Agr. Eng. Annu. Meet., paper 71-165.

Stupendick. J.T. and K.R. Shepherd. 1979. Root regeneration of root-pruned Pinus radiata seedlings. I. Effects of air and soil temperature. Austral. For. 42:142-149.

Sutton, R.F. 1969. Form and development of conifer root systems. Commonw. Agr. Bur., Commonw. For. Bur., Oxford, Tech. Commun. 7.

Sutton, R.F. 1975. Biological aspects of mechanized regeneration, p. 98122. In: Mechanization of silviculture in northern Ontario. Dept. Environ., Can. For. Serv., Sault Ste. Marie, Ont., Symp. Proc. O-P-3.

Sutton, R.F. 1977. Stock quality and grading, p. 16-17. In: R.F. Sutton (ed.). Plantation establishment symposium. Environ. Can., Can. For. Serv., Sault Ste. Marie, Ont., Symp. Proc. O-P-5.

Sutton, R.F. 1978. Root system development in young outplants, particularly white spruce, p. 172-185. In: E.E. Van Eerden and J.M. Kinghorn (eds.). Root form of planted trees symposium proceedings. B.C. Min. For./Can. For. Serv., Victoria/Ottawa, Joint Rpt. 8.

Sutton, R.F. 1979. Planting stock quality and grading. For. Ecol. Mgt. 2:123-132.

Sutton, R.F. 1980a. Techniques for evaluating planting stock quality: International Union of Forest Research Organizations (IUFRO) Workshop, New Zealand, Aug. 1979. For. Chron. 56:118-120.

Sutton. R.F. 1980b. Root system morphogenesis. New Zealand J. For. Sci. 10:264-292.

Sutton, R.F. 1980c. Planting stock quality, root growth capacity, and field performance of three boreal conifers. New Zealand J. For. Sci. 10:5471.

Sutton, R.F. 1982a. Plantation establishment in the boreal forest: planting season extension. Dept. Environ., Can. For Serv., Sault Ste. Marie, Ont., Info. Rpt. O-X-344.

Sutton. R.F. 1982b. Plantation establishment with bare-root stock: Some critical factors, p. 304-331. In: G.D. Mroz and J.F. Berner (eds.). Artificial regeneration of conifers in the Upper Great Lakes region 1982. Michigan-Tech. Univ., Houghton.

Sutton, R.F. 1983. Root growth capacity: Relationship with field root growth and performance in outplanted jack pine and black spruce, p. 111-122. In: D. Atkinson, K.K.S. Bhat, M.P. Coutts, P.A. Mason, and D.J. Read (eds.). Tree root systems and their mycorrhizas. Nijhoff/Junk, The Hague, The Netherlands.

Sutton, R.F. and R.W. Tinus. 1983. Root and root system terminology. For. Sci. Monogr. 24.

Sutton, R.F. 1987. Root growth capacity and field performance of jack pine and black spruce in boreal stand establishment in Ontario. Can. J. For. Res. 17:794-804.

Tabbush, P.M. 1986a. Rough handling reduces the root growth potential and survival of barerooted conifer transplants. Quart. J. For. 80:185-188.

Tabbush, P.M. 1986b. Rough handling, soil temperature, and root development in outplanted Sitka spruce and Douglas-fir. Can. J. For. Res. 16:1385-1388.

Takahashi, H. and M.J. Jaffe. 1984. Thigmomorphogenesis: the relationship of mechanical perturbation to elicitor-like activity and ethylene production. Physiol. Plant. 61:405-411.

Thompson, B.E. and R.T. Timmis. 1978. Root regeneration potential in Douglas-fir seedlings: effect of photoperiod and air temperature on its evaluation and control, p. 86-109. In: A. Riedacker and J. GagnaireMichard (eds.). Root physiology and symbiosis. Proc. IUFRO Symp., Nancy, France.

Torrey, J.G. and D.A. Phillips. 1974. Hormonal interactions between root and shoot: The root as site of hormone synthesis, p. 17-23. In: G. Hoffmann (ed.). Ecology and physiology of-root growth. Akademie Verlag, Berlin.

Troughton, A. and W.J. Whittington. 1969. The significance of genetic variation in root systems, p. 296-313. In: W.J. Whittington (ed.). Root growth. Butterworths, London.

van den Driessche, R. 1978. Seasonal changes in root growth capacity and carbohydrates in red pine and white spruce nursery seedlings, p. 6-19. In: A. Riedacker and J. Gagnaire-Michard (eds.). Root physiology and symbiosis. Proc. IUFRO Symp., Nancy, France. 
van den Driessche, R. 1983. Growth, survival and physiology of Douglasfir seedlings following root wrenching and fertilization. Can. J. For. Res. $13: 270-278$

Wakeley, P.C. 1935. Artificial reforestation in the Southern pine region. USDA For. Serv. Tech. Bul. 492.

Wakeley, P.C. 1949. Physiological grades of Southern pine nursery stock. Proc. Soc. Amer. For. 1948. 43:311-322.

Wakeley, P.C. 1971. Lectures in forestry. Clemson Univ. Coll. For. Recreation Resources, Dept. For., Clemson Univ., Clemson, S.C. For. Res. Ser. 23.

Walters, J. and J. Soos. 1961. The effect of months of planting upon survival and growth of Douglas-fir and Scots pine seedlings. Univ. B.C., For. Res. Paper 38.
Weaver, R.J. 1972. Plant growth substances in agriculture. Freeman, San Francisco.

Winjum, J.K. 1963. Effects of lifting date and storage on $2+0$ Douglas-fir and noble fir. J. For. 61:648-654.

Zaerr, J.B. 1967. Auxin and the root-regenerating potential in ponderosa pine seedlings. For. Sci. 13:258-264.

Zaerr, J.B. and D.P. Lavender. 1974. The effects of certain cultural and environmental treatments upon the growth of roots of Douglas-fir (Pseudotsuga menziesii [Mirb.] France) seedlings, p. 27-32. In: G. Hoffmann (ed.). Ecology and physiology of root growth. Akademie Verlag, Berlin. Zobel, R.W. 1975. The genetics of root development, p. 261-275. In: J.G. Torrey and D.T. Clarkson (eds.). The development and function of roots. Academic, London. 